\title{
Implications of the Inquiry Strategy on Science Process Skills and Students Learning Outcomes in Learning Growth and Development Systems of Plants at SMA and MA Negeri Kembang Tanjong Pidie Regency
}

\author{
Muhammad Hafidillah ${ }^{1}$, Hasanuddin $^{2}$, Ali Sarong ${ }^{3}$ \\ ${ }^{1}$ Student of Post graduate at University of Syiah Kuala, Indonesia \\ ${ }^{2,3}$ Lecturer of Post Graduate at University of Syiah Kuala, Indonesia \\ Mhafidilah.mpbio15@edu.unsyiah.ac.id
}

\begin{abstract}
This study aimed to determined the differences between learning with free inquiry strategies on science process skills and learning outcomes on the materials of growth and development at SMA and MA in Kembang Tanjong, Pidie Regency. Data was collected on 6 October to 10 November 2018. This study use a quantitative descriptive approach with a quasi-experimental research technique. The design in this study is a non-equivalent control group design. The collecting of data divided into two groups: the experimental group and the control group. The number of samples in this study were 50 students for the experimental class and 52 students for the control class. Hypothesis this study testing based on the SPSS program version 23.0 for windows of a significance level of 0.05 obtained results; the value of science process skills students 6,055> 1.98 (thitung $>$ $\left.t_{\text {tabel }}\right)$, the value of student learning outcomes of a significance level of 0.05 obtained sig value is 5.965> 1.98 ( $\left.t_{\text {hitung }}>t_{\text {tabel }}\right)$. Based on two variables measured show that the implementation of the inquiry strategy there are differences between the science process skills and student learning outcomes in the material growth and development in plants at SMA and MA Negeri KembangTanjong, Pidie Regency.
\end{abstract}

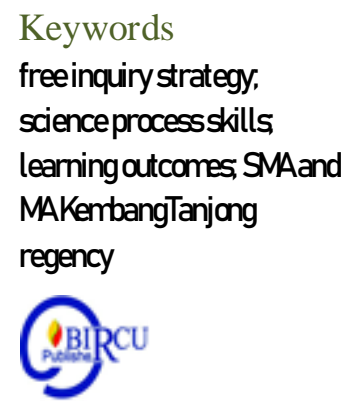

\section{Introduction}

Biology is a vehicle to increase knowledge, skills, attitudes, and values. Biology deals with how to find out and how to understand nature systematically. in other words, biology does not only involve mastery of a collection of knowledge in the form of facts, concepts, and principles, but also is a process of discovery (Departemen Pendidikan Nasional, 2003) . Process skills include observing skills, proposing hypotheses, using tools and materials properly and always considering work safety and safety, asking questions, classifying and interpreting data, and communicating findings verbally or in writing, exploring and sorting out relevant factual information for testing ideas or solving everyday problems (Dahar, 2011).

Science process skills are a complex set of abilities commonly used by scientists in conducting scientific investigations in a series of learning processes. Science process skills are a series of activities that can be measured from practicum activities, as the best means of developing process skills (Rustaman, 2005). The inquiry strategy can be realized through practicum activities. 
Inquiry requires a higher order of thinking. Through inquiry the teacher provides input for students with problems to investigate along with procedures and materials. This type of inquiry learning is used to teach certain concepts, facts or skills and lead ways to open inquiry where students formulate their own problems to investigate (Brickman, et. al. 2009). Students will master the concepts and principles that are good if they have good science process skills. The success of students in understanding learning matirials, depends on the teacher as a guide who must act as a good motivator and facilitator. When teaching and learning should be actively involved in the teaching and learning process. This is reflected in the activities of students in learning not only as recipients of subject matter. According to Munandar (1999) states learning with a non-authoritarian atmosphere, where teachers put confidence in the ability of students to think and dare to express new ideas. When students are given the opportunity to work according to their interests and needs, their creative abilities and flourish.

The success of the teaching and learning process is directly influenced by the strategies used by the teacher in teaching. Inquiry strategy gives students the opportunity to solve problems in learning independently. The use of inquiry strategies is expected to open students' insights to find concepts from the experience of working independently or in groups. The inquiry strategy is described as a student-centered approach. Students in this approach, form their own problems and hypotheses, make plans for scientific research, conduct this research to test their hypotheses and discuss their findings with other friends (Hassard, 2005). This type of inquiry learning is used to teach certain concepts, facts or skills and lead the way to open inquiry where students formulate their own problems to investigate, one of the concepts taught through inquiry strategy is Growth and development.

Based on begining of the survay at SMA/MA Kembang Tanjong district that consist of two high school and one Madrasah Aliyah that is SMA Negeri 1 Kembang Tanjong, SMA Negeri 1 Glumpang Baro and MAN 3 Pidie, where SMA Negeri 1 Glumpang Baro is fomerly is part of Kembang Tanjong district. based on the location and distance of the school is very close, the researchers involved SMA Negeri 1 Glumpang Baro as a sample in this study. Based on preliminary survey results it was found that biology learning in SMA / MA Kembang Tanjong sub-district was still dominated by the behavioristic paradigm which considers knowledge to be memorized facts and teachers as the main source of knowledge. In this paradigm, teachers do not involve students in learning activities such as not learning students in groups and not doing group inquiry. The teacher also does not involve students in learning planning, does not conduct project assessments, does not conduct group discussions and does not present the results of discussions to the class. The main demands of education open students' insights to find concepts from the experience of working independently or in groups.

The understanding of students' learners toward learning matirials will be realized, if the students themselves are directly involved in understanding learning matirials. Students are involved with reading books, making conclusions, explaining verbally, asking questions and answering questions. All this can be done group discussion and class discussion by paying attention to the differences between students so as to create a pleasant classroom atmosphere. The conducive atmosphere is inseparable from the involvement of the teacher as a motivator and facilitator.

The reality is obtained at SMA / MA Kembang Tanjong Subdistrict, seen by many students who considered learning biology difficult to understand, because students were less involved in the teaching and learning process. This can be seen in the ongoing teaching and 
learning process namely the lack of student learning activities and the low learning outcomes. The low learning outcomes is one of them caused by teacher factors in implementing learning strategies. Some teachers have not been able to develop the creativity of students in learning and are less optimal in involving students in learning. Based on these, the teacher must be clever in compiling the learning scenario. Learning that emphasizes memorization methods and seeks one correct answer must be immediately abandoned and turn to learning designs that allow students to express creativity and science process skills.

\section{Literature Review}

\subsection{Inquiry Strategy in Biology Learning}

Biology is a natural science that studies life in the world from all aspects, both about living things, the environment, and interactions between living things and their environment. Therefore, it is not uncommon to find things called miracles when studying this science. Learning from biology that is applied in the world today is the result of research from scientists, and this result can be proven and does not deviate from the facts. At present the development of biology supported by technological advances has given birth to many other branches of science.

Biology learning is very compatible with inquiry methods that involve learning in process skills such as observing, classifying, measuring, predicting, explaining, and concluding. In carrying out these processes, teacher assistance is needed. However, the teacher's assistance must be increasingly reduced by the more mature students or the higher class of students.

Biology is essentially knowledge of the concepts of life in the universe that includes animals, soil, humans, and microorganisms with all its diversity. The process of learning biology through a series of scientific thinking processes, the end of the learning outcomes of the material is expected that students are motivated to develop knowledge, skills, scientific attitudes, love, and appreciate the greatness of the Creator, even more broadly after students have finished studying biology there are changes in behavior not only about changing knowledge but also in the form of skills, habits, attitudes, understandings, appreciation, interests, adjustment, in short regarding all aspects of the organism.

Learning by discovery (inquiry) is an important component in a constructivist approach that has a long history of innovation or educational renewal. Learning by discovery / inquiry, learners are encouraged to learn mostly through their own active involvement with concepts and principles, and the teacher encourages students to have experience and conduct experiments that enable them to find principles for themselves.

Learning by inquiry strategy teaches a study material not to produce a living library of the study material, but rather is shown to make students think for themselves, emulate what historians do, they take part in the process of gaining knowledge. Knowing is a process, not a product (Nur \& Wikandari, 2000). Learning by discovery can be applied in many subjects. Jones and Eick explain inquiry learning is an active process and describes scientific inquiry that takes place in the context of formal education. Based on Sanjaya (2005) states inquiry is a technique or method used by teachers to teach in front of the class. In its implementation the teacher gives assignments in the form of problems in class. Learners are divided into groups, and each group gets a specific task that must be done. Then they study, research or discuss their assignments in groups. After their work is discussed, a well-structured report is then made. 
Learning with discovery has several advantages. Learning with inquiry strategy spurs students' desire to know, motivates them to continue their work until they find the answer. Students also learn to solve problems independently and have critical thinking skills because they must always analyze and handle information. Inquiry teaching requires teaching strategies that follow scientific methodologies and provide opportunities for meaningful learning. Inquiry is the art and science of asking and answering. Inquiry involves observation and measurement, making hypotheses and interpretations, forming strategies and testing strategies. Inquiry demands experimentation, reflection and recognition of its own strengths and weaknesses.

\subsection{The Skills of Sciences Process}

Skills are the ability to use thoughts, reason and actions efficiently and effectively to achieve a certain result, including creativity. According to Sandra (1990), that in science learning activities students should not only learn the concepts or products contained in the science subject matter but must include other components, including the components of science process skills.

Creative people are those who have an extraordinary ability to adapt to all situations and their skills are able to carry out their work to achieve the desired goals. Usually creative people are always curious, have broad interests, have fun and love creative activities. The characteristics of creative learners according to Munandar (1999) are imaginative, have initiative, have broad interests, are independent in thinking, researching, happy to be adventurous, full of energy, confident, willing to take risks, courageous in their convictions and beliefs.

According to Soeparwoto (2004) the characteristics of creativity are; great curiosity, often asking good questions, giving many ideas or proposals to a problem, free to express an opinion, stand out in one of the arts, have their own opinions and can express / not easily influenced by others, strong imagination, originality high (visible in ideas, essays, and so on and using originality in problem solving), can work alone and enjoy trying new things.

Science process skills are the ability of students to apply scientific methods in understanding, developing and discovering science. Science process skills are also called a series of activities that can be measured from practicum activities. The science process skills in this study are in accordance with the indicators of science process skills, namely: observing, grouping, predicting, asking questions, hypothesizing, planning experiments, using tools / materials, applying concepts, and communicating.

Process skills are a learning approach that emphasizes the learning process, activities and creativity of students in obtaining knowledge, skills, values and attitudes, and applying them in everyday life (Mulyasa, 2005). The process skills approach can be interpreted as an insight or role model for developing intellectual, social and physical skills that originate from fundamental abilities that the principle already exists in learners. The process skills approach to science learning places more emphasis on forming skills to gain knowledge and communicate the results.

The process skills approach is intended to develop the abilities possessed by individual students. Dimyati \& Mudjiono (2002) contains a review of the process skills approach taken from Funk (1985) as follows. First, the process skills approach can develop the nature of students' knowledge. Students are encouraged to gain knowledge well because they better understand the facts and concepts of science. Second, learning through process skills will give students the opportunity to work with science, not just tell stories, and or listen to the 
history of science. Third, process skills can be used by students to learn the process and also the product of science. The approach to science process skills gives students the opportunity to actually act as a scientist.

\subsection{Learning Outcomes}

\section{a. Understanding Learning Outcomes}

Learning outcomes according to Suprijono (2009) "Patterns of actions, values, understanding, attitudes, appreciation and skills. Learning outcomes in education today are better known as Bloom's taxonomy, what is meant by this taxonomy is a way to classify complex things, meaning to classify in stages, from the simplest to the most complicated abilities. In accordance with the taxonomy of learning objectives, learning outcomes are distinguished in three aspects namely cognitive, affective and psychomotor aspects (Suprahatiningrum, 2013).

- Cognitive aspect

Cognitive dimensions are abilities related to thinking, knowing and solving problems, such as comprehensive knowledge, applicative, synthesis, analysis and evaluative knowledge. Cognitive areas are areas that discuss learning goals regarding mental processes that begin at the level of knowledge to a higher level, namely evaluation.

- Affective aspect

Affective dimension is the ability related to values, attitudes, interests and appreciation. According to Uno (2007), there are five levels of affection from the simplest to the most complex, namely the willingness to accept, the willingness to respond, to believe, the application of works and the perseverance and accuracy.

- Psychomoric aspect

Psychomotor areas include goals related to skills that are manual or motoric. Like the other two domains, this domain also has various levels. The simplest sequence to the most complex is perception, readiness to carry out an activity, mechanism, guided responses, skills, adaptation and organization.

\section{b. Factor Affecting of Learning outcomes}

Learning outcomes are the addition of knowledge, skills, abilities and changes in behavior after the whole series of learning activities has been completed (Wuryani, 2002). Learning outcomes achieved by participants are learning outcomes obtained through the learning process and are influenced by internal and external factors.

Two factors that also influence the process and learning outcomes, these factors originate from within the human being itself or are called internal factors, and factors originating from outside the human self or called external factors. One important aspect of cognitive development that is closely related to external factors is perception. "Perception is someone's interpretation of a stimulus" (Trianto, 2007)

\subsection{Relationship between Science Process Skills and Learning Outcomes}

Science process skills are very important to be developed in education because they are the basic competencies to develop students' scientific attitudes and problem solving skills, so that they can form creative, critical, open, innovative, and competitive learners in competition in the global world in society. In addition, some of the reasons underlying the need for process skills in teaching and learning activities were stated by Semiawan (1990) that learners more easily understand complicated and abstract concepts if accompanied by 
concrete examples or through tangible objects, so students learn actively and creatively in develop skills to process the acquisition of concepts. Semiawan (2002) states that the skilled process is very closely related to the creative process. The stages that must be carried out in the creative process are preparation (preparation), incubation (incubation), illumination (illumination), verification (verification). Through this stage skilled processes will begin to be seen. One of the skilled processes in science is process skills. Semiawan (1990) states the process skills of students include observation activities (observation), the formulation of hypotheses, research planning, controlling variables, interpretation of data, temporary conclusions, forecasting, application and communication.

\subsection{Material for Growth and Development in Soil}

Growth and development are two processes that run simultaneously. So the process of growth and development cannot be separated from one another. Every living thing experiences a process of growth and development.

Growth is the process of increasing the number or size of cells that cannot return to their original form (irreversible), and can be measured (expressed in numbers or graphs). For example, seed sprouts grow into mature soil.

Development is a process leading to maturity / maturation, can not be measured but can only be observed. At the cellular level, development can be in the form of differentiation of cells that just divide to form tissues that make up certain organs. In soil, development is marked by the appearance of flowers or fruit. Growth and development in higher soil begins with seeds. Seed is the result of fertilization between the spermatozoid and the ovum that grows into zygotes. The zygote then grows into an embryo. Furthermore, the embryo will germinate to produce young individuals.

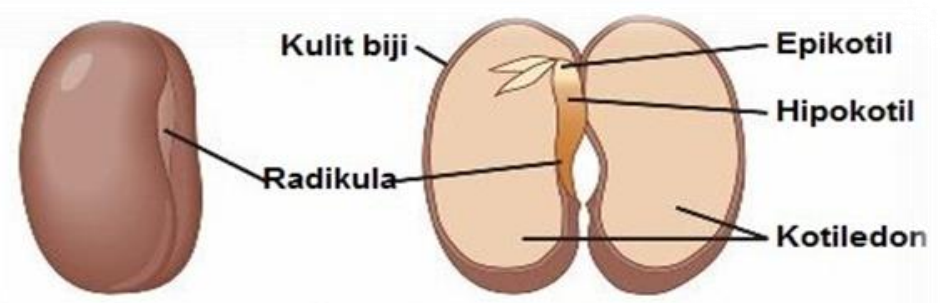

a) Biji kacang hijau, dikotil dengan kotiledon tebal
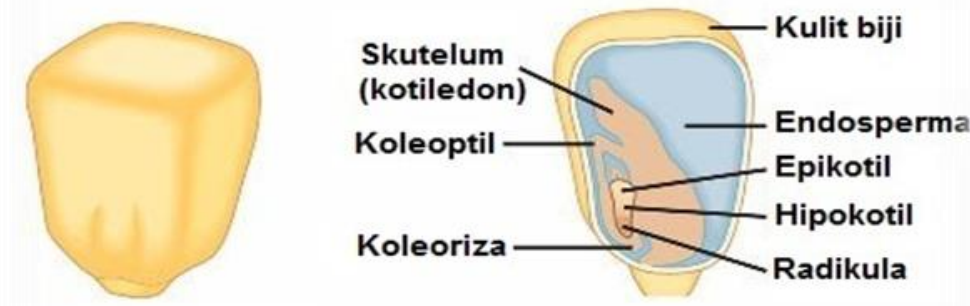

b) Jagung, monokotil

Figure 1. Structure of Dicotyledon and ,

\section{a. Process of Growth and Development of Soil}

- Germination

Physiology of Germination 
Seed germination starts at the end of the seed dormancy period. This is marked by the absorption of water into the seeds (Imbibisi). Water entering the seeds will release the hormone gibberellins which will stimulate the aleuron to secrete enzymes as biocatalysts in seed metabolism.

The results of the germination process in the form of growth and development of plumules into stems and leaves and the development of radicles into roots. The newly grown embryo does not yet have chlorophyll so it cannot yet carry out photosynthesis to produce its own food. Food for embryos is obtained from endosperm (Irnaningtyas, 2015).

\section{- The Germination Type}

Based on the position of the cotyledons in the sprouts, the type of germination can be divided into two, including:

\section{Epigeal type germination}

The type of epigeal germination is characterized by hypocotyl growing lengthwise so that the plumula and cotyledon are raised upward (ground level). Cotyledons can carry out photosynthesis as long as the leaves have not formed. Examples of this plant are green beans, soybeans, sunflowers and peanuts. The first organ that appears when seeds germinate is radicles. These radicles will then grow through the soil surface. For dicotyledon soil that are stimulated with light, the hypocotyl stem segment will grow straight to the ground lifting cotyledons and epicotiles. The epicotyl will first appear and then the cotyledons will fall out when the food reserves in them have been used up by the embryo (Campbell et al., 2000: $365)$.

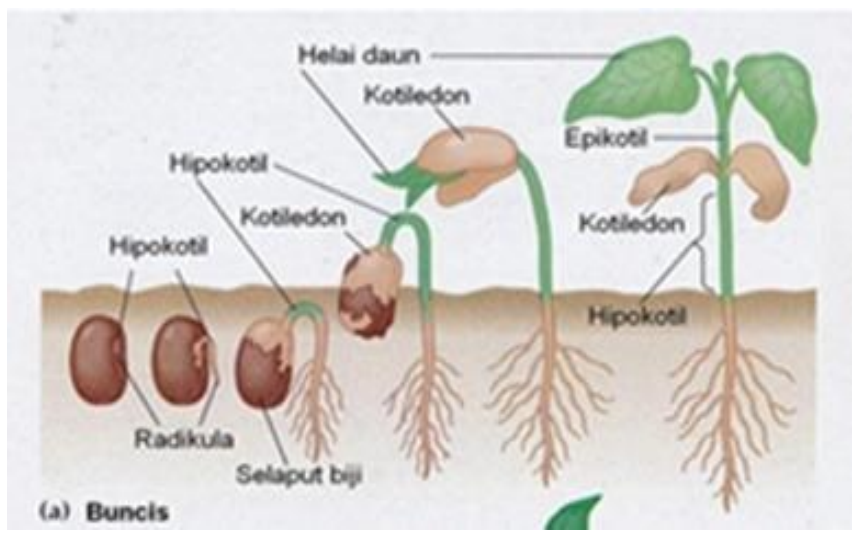

Figure 1. Epigeal type germination (Source: Campbell et al., 2000:365)

\section{Hypogeal Type germination}

Hypogeal germination is characterized by an epicotile that grows elongated then the plumula grows to the surface of the ground through the seed coat. Cotyledons remain in the soil. Examples of soil that experience this germination are peas, peas, corn, and embryo grass (Campbell et al., 2000). 


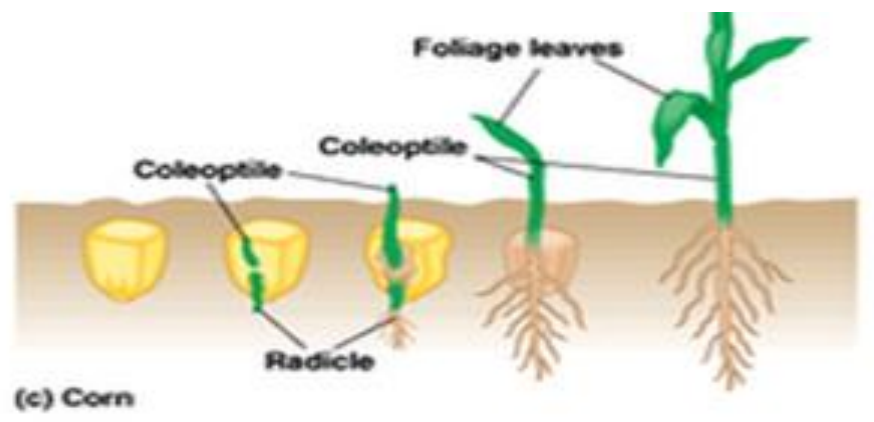

Figure 2. Hypogeal Type germination

(Source: Campbell et al., 2000:366)

\section{b. The Primary Growth}

Primary growth is growth that occurs due to primary meristem tissue activity or also called apical meristem. The primary growth point is formed since the plant is still in the form of an embryo. This meristem network is located at the tip of the stem and root end. As a result of this growth, plant roots and stems grow longer.

At the growing point, growth occurs gradually. Therefore the growth area can be divided into three, namely the cleavage region, the extension region, and the differentiation region.

\section{Cleavage area}

Cleavage area is located at the very end. In this area new cells are constantly produced through the process of cell division. This area is called meristematis area.

\section{Elongation area}

The elongation area is located behind the cleavage area. In this area the cells resulting from division will grow so that the cell size increases. As a result, it is in this area that has been lengthened.

\section{Area of differentiation}

The area of differentiation is located behind the elongation area. Cells that have grown undergo changes in form and function. Some cells undergo differentiation into epidermis, cortex, xylem, and phloem. Some form parenchyma, colenchyma, and sclerenchyma.

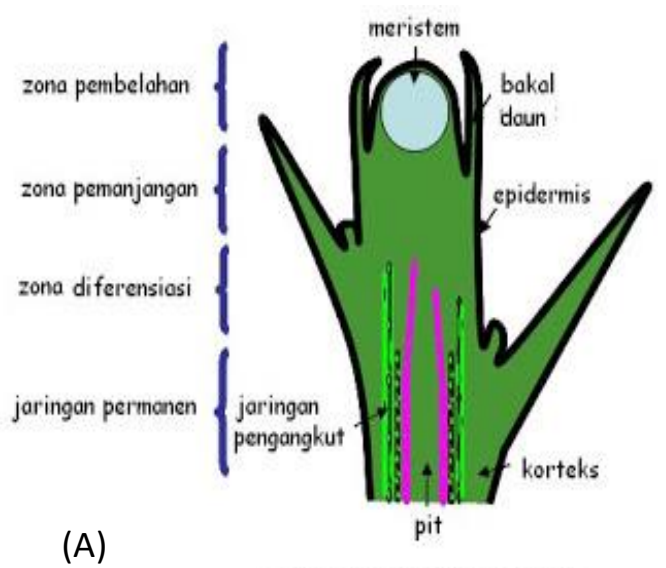

MERISTEM APIKAL BATANG

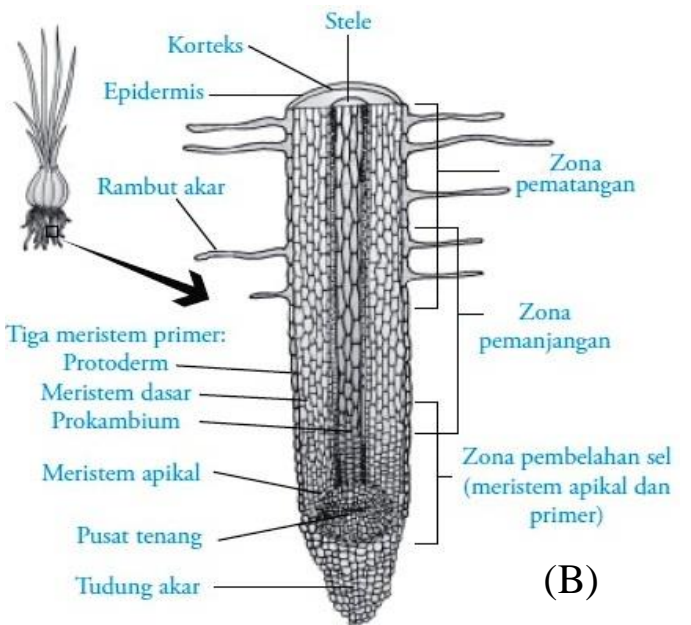

(B)

Figure 3. (A) Premery growth of Stems, (B) Premery Growth of kouts

(Source: Campbell et al., 2000:362) 


\section{c. The Secondary Growth}

Secondary growth is the result of secondary meristem tissue activity, namely cambium vessels and cork cambium (phelogens). In general, secondary growth occurs on the stem of Gymnosperms and dicotyledonous soil. Monocotyl soil do not experience secondary growth, except woody monocots, especially Agave, Aloe, Dracaena, Pandanus, and Yucca.

Vascular tissue is located between the xylem tissue (wooden vessels) and phloem vessels (skin vessels). The division of vascular cambium cells occurs radially, which divides outward to form secondary phloem and divide inward to form secondary xylem (Irnaningtyas: 2015).

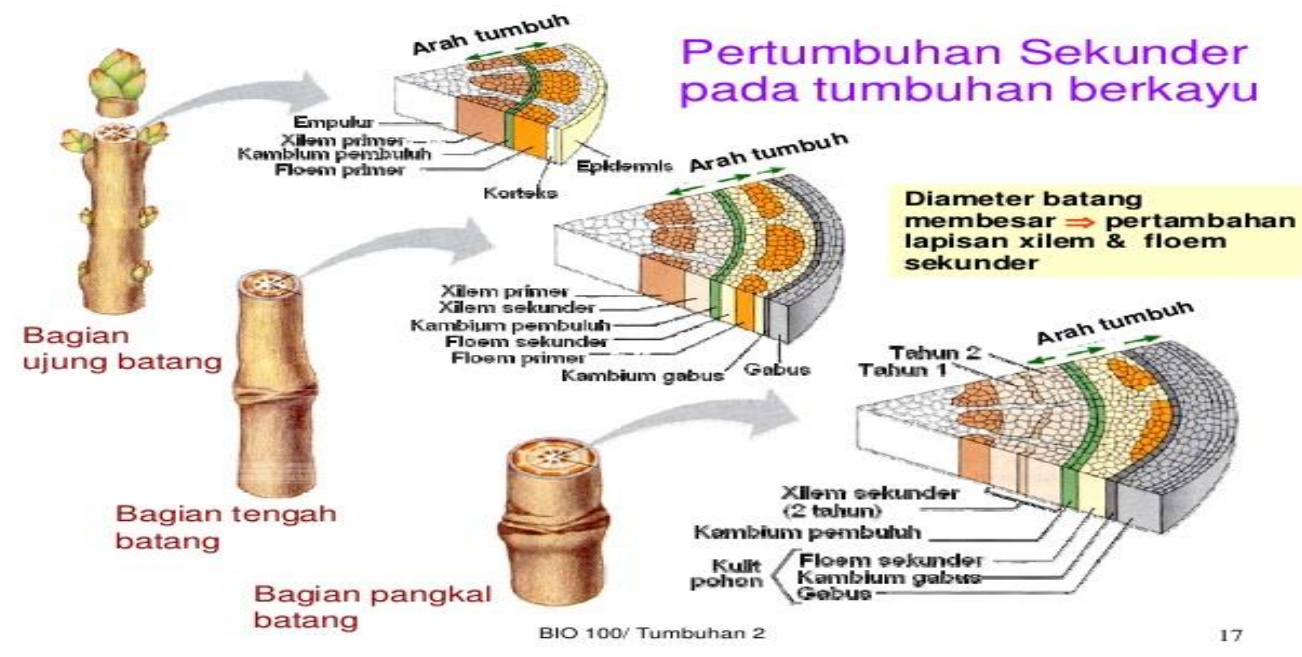

Figure 4. Secondary Growth in Woody Plants

(Source: Campbell et al., 2000:364)

In annual soil (perennial), secondary growth occurs for many years so that the secondary xylem layer after layer forms wood with a circular formation called a growth circle (year circle). The formation of a circle grows in the rainy season the layer is thicker than the layer formed in the dry season. During the rainy season, the quantity of water absorbed from the soil increases and secondary xylem growth will be faster. Conversely, in the dry season,

the intensity of water absorption decreases so that the secondary xylem formed will be smaller and appear darker in color because the cells are denser and drier due to lack of water.

The growth circle allows us to estimate the age of a tree.

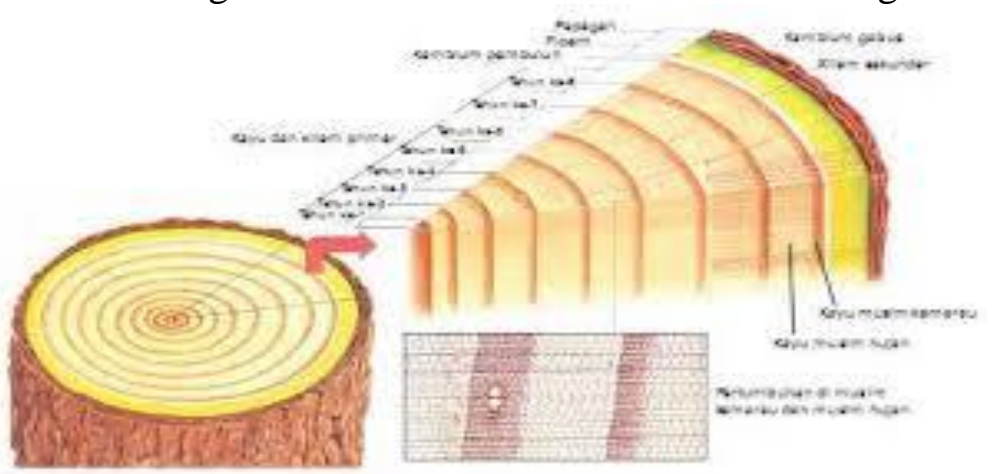

Figure 5. Circles of growth on woody plants

(Source: Campbell et al., 2000: 364) 
Factors that affect growth and development in plants can be divided into internal factors and external factors.

\section{- Internal Factor}

Internal factors that influence growth and development originate in the body of living things themselves, this category is a factor of genes and hormonal states

\section{Gen}

Genes are substances that carry traits inherited from the parent. Genes influence the characteristics and characteristics of living things, such as body shape, body height, skin color, flower color, feather color, fruit flavor, and so on. Genes also determine the metabolic ability of living things, thus affecting their growth and development. Animals, soil, and humans who have good growth genes will grow and develop quickly according to their growth and development period. Although the role of genes is very important, genetic factors are not the only factors that determine patterns of growth and development, because they are also influenced by other factors.

\section{Hormon}

Hormones are substances that function to control various functions in the body. Although the levels are small, hormones exert a significant influence in regulating various processes in the body. Hormones in soil are often called phytohormones or body regulatory substances. Some of them are auxin, cytokinin, gibberellins, ethylene, abscisic acid, kalin, and traumalin acid:

a) Auxin, serves to stimulate cell extension, stimulate the formation of flowers, fruit, and activate cambium to form new cells

b) Cytokines, stimulate cell division and accelerate the formation of roots and shoots.

c) Gibberellins, stimulate cell division and enlargement and stimulate seed germination. In certain soil, gibberellins can cause flowers to appear more quickly.

d) Ethylene, acts to inhibit stem elongation, accelerate fruit aging, and cause leaf aging.

e) Abscisic acid plays a role in the process of leaf removal and seed dormancy. flowers.

f) Kalin, plays a role in stimulating the formation of root organs, stems, leaves, and

g) Traumalin acid, functions to stimulate cell division in plant parts that are injured. This event only occurs in dicotyledonous soil.

\section{- External Factor}

External factors that influence the process of growth and development of living things come from environmental factors. Some environmental factors that affect the growth and development of living things are as follows.

\section{Food or Nutrition}

Food is the raw material and source of energy in the body's metabolic processes. The quality and quantity of food will affect the growth and development of living things. Because it is in its infancy, you should eat enough nutritious food to support the growth and development of your body.

Nutrients needed by humans and animals are carbohydrates, proteins, fats, vitamins, and minerals. All these substances are obtained from food. As for soil, the nutrients needed are water and nutrients dissolved in water. Through the process of photosynthesis, water and carbon dioxide (CO2) are converted into food substances with the help of sunlight. Although it does not play a direct role in photosynthesis, nutrients are needed so that soil can grow and develop properly. Try to observe, late-fertilized rice soil, the leaves will turn yellowish. Once 
fertilized, the leaves of the rice plant will return to green and grow well. Why is that? In the fertilizer contained nutrients that are important as plant nutrients.

\section{Temperature}

All living things need suitable temperatures to support their growth and development. This temperature is called the optimum temperature, for example a normal human body temperature is around $37^{\circ} \mathrm{C}$. At the optimum temperature, all living things can grow and develop properly. Animals and humans have the ability to survive within a certain ambient temperature range. Soil show a more pronounced influence on temperature. Rice planted at the beginning of the dry season (high average temperature) is harvested faster than rice planted in the rainy season (low average temperature). A type of rose that grows and blooms well in the cool mountains, when planted in hot coastal areas its growth slows and does not produce flowers as beautiful as before. This is because all processes in growth and development such as water absorption, photosynthesis, evaporation, and respiration in soil are affected by temperature.

\section{Radiance}

Radiance affects the growth and development of living things. Soil really need sunlight for photosynthesis. However, the presence of light can actually inhibit plant growth because light can damage the auxin hormone found at the end of the stem. If you store the sprouts in a dark place for several days, the sprouts will grow faster (taller) than they should, but look weak and pale / yellowish due to lack of chlorophyll. In addition to soil, humans also need sunlight to help form vitamin D.

\section{Water and moisture}

Water and moisture are important factors for growth and development. Water is needed by living things. Without water, living things cannot survive. Water is a place where chemical reactions take place in the body. Without water, chemical reactions in cells cannot take place, which can result in death.

\section{Soil}

For soil, soil influences their growth and development. Soil will grow and develop optimally if the soil conditions in which they live fit the nutritional and nutrient requirements. Soil conditions are determined by other environmental factors, such as temperature, mineral content, and water.

\section{Research Method}

This research conducted at SMA / MA Kembang Tanjong Subdistrict, namely SMA Negeri 1 Kembang Tanjong, SMA Negeri 1 Glumpang Baro and MAN 3 Pidie. Data collection was carried out in the even semester of the 2017/2018 school year from June to August 2018.

The types of instruments used in this study include observation sheets of science process skills, learning achievement test instruments and learning implementation instruments.

Observation sheet to measure students' scientific process skills in the learning process. This observation sheet processing is done by scoring for all aspects of science process skills based on indicators. 


\section{Discussion}

Research on the implications of the free inquiry strategy influences the science process skills and learning outcomes of students on growth and development material in soil in the SMA / MA Kembang Tanjong Subdistrict, Pidie District has been completed on November 10,2018

The research process includes several stages, namely the preparation phase, the data collection stage, and the analysis phase. The preparation phase includes the stages of preparing learning tools such as Syllabus, Learning Implementation Plan (RPP), Student Worksheet (LKPD), observation sheet to measure science process skills and multiple choice questions for cognitive tests of student learning outcomes.

Data collection phase includes the stage of researching and testing research instruments, where the researcher collects preliminary data in the form of student cognitive test results before learning (pretest) in the experimental class and the control class. Posttest instruments consisted of 30 multiple choice questions. The next meeting the researchers conducted a teaching and learning process (PBM) in the experimental class with the free inquiry strategy and in the control class with conventional learning. At the fourth meeting after learning ended in the experimental class and the control class the researcher returned to collect data about the science process skills and student learning outcomes. Data for learning outcomes (pretest) were collected with a test instrument in the form of multiple choice questions of 30 questions. Retrieval of data about students' science process skills is done by using an observation sheet on the practical work activity LKPD.

The analysis phase is the processing of the results obtained from the data collection stage into quantitative data that is measured and processed using the SPSS 23.0 for windows application. Hypothesis testing in this study was conducted with parametric statistics using Independent Sample t-Test.

Research that has been carried out obtained data about science process skills and student learning outcomes on growth and development material in soil that are applied using inquiry strategies in the experimental class and conventional learning in the control class. This research was conducted in class XII (Twelve) Glumpang Baro High School, MAN 7 Pidie, and High School 1 Kembang Tanjong. In this study, the total number of students was 150 students divided into 2 groups: the experimental group by 73 students, and the control group by 77 students.

This study uses two types of learning, namely learning by using free inquiry in the experimental class and conventional learning in the control class. The results of this study will be described in accordance with the variables studied in the three SMA / MA Negeri in the Pidie Regency Region.

\section{Conclusion}

Based on the results of research on the implications of a free inquiry strategy on science process skills and student learning outcomes in learning the growth and development systems in soil in state high schools in Pidie District, it can be concluded that:

a. Based on the results of the $t$ test showed that there is an influence on students' Science Process Skills between the experimental class and the control class. This can be seen in table 4.1 the column of significance showing that $t$-cout $>t$-tabel at a significant level 0,05 that is $7,443>$ which means that there is an influence of inquiry strategy on students' science process skills on growth and development material in soil. 
b. Based on the results of the $t$ test at a significance level of 0.05 obtained sig values are 7.733> 1.98 (t-count $>t$-table) and Sig (2-tailed) $0.000<0.05$ indicate that the data is significant or significantly different between classes experiment and control class. That is, the application of inquiry strategy influences student learning outcomes on growth and development material in soil.

c. The effect of learning with free inquiry strategy is seen from the results of the average difference test at the significance level $(\alpha=0.05)$ it is known that the value of $p$ (sig) is $0,000<0.05$. So the hypothesis (H1) which states that there is an influence of learning with free inquiry strategy on science process skills on growth and development material in soil is accepted.

\section{References}

Arikunto, S. 2010. Prosedur Penelitian Suatu Pendekatan Praktik. Jakarta: Rineka Cipta

Brickman, P., 2009. Effects Of Inquiry-based learning on Students' Science Literacy Skills and Confidence. International Journal for the Scholarship of Teaching and Learning. 3 (2). 1-22

Campbell, N.A., J.B.Reece dan L.G. Mitchell. (2000). Biologi Jilid II. Jakarta. Erlangga.

Carin, A.A. \& Sund, R.B. 1975. Teaching Science trough Discovery, $3^{\text {rd }}$ Ed. Columbus: Charles E. Merrill Publishing Company.

Dahar, R.W. 2011. Teori-Teori Belajar. Jakarta: Erlangga.

Delismar. Ashyar, R,. Hariyadi, B. 2013. Peningkatan Kreativitas dan Keterampilan Proses Sains Siswa melalui Penerapan Model Group Investigation. Jurnal Edu-Sains 1 (2). 25 32

Departemen Pendidikan Nasional, 2003. Standar Kompetensi Mata Pelajaran Biologi Sekolah Menengah Atas dan Madrasah Aliyah. Jakarta: Balitbang Depdiknas.

Endah, N. 2015. Pengembangan Modul Ipa Terpadu Berbasis Inkuiri Terbimbing Dengan Tema Barbeque Kelas VII SMP Negeri 1 Tawangmangu. Jurnal Pendidikan IPA Surakarta: FKIP Universitas Sebelas Maret Vol 4 No 4.

Gulo, W. 2008. Strategi Belajar Mengajar. Jakarta: Grasindo

Hassard. J. 2005. The Art of Teaching Science: Inquiry and Innovation in Middle and High School. Oxford University Press. Oxford New York

Joyce, B., Weil, M., \& Calhoun, E. 2011. Model-Model Pengajaran. Terjemahan Achmad Fawaid dan Ateilla Mirza. Yogyakarta: Pustaka Pelajar

Kim, K. H., \& VanTassel-Baska, J. (2010). The relationship between creativity and behavior problems among underachievers. Creativity Research Journal, 22, 185-193.

Langgulung, H. 1991. Beberapa Tinjauan dalam Pendidikan Islam. Kuala Lumpur. Pustaka Antara.

Lefrancois, G. R. 1996. Psychology for Teaching. Belmont. California: Wadsworth Publishing Company.

Mahanal, S. 2009. Pengaruh Pembelajaran Project Based Learning pada Materi Ekosistem terhadap Sikap dan Hasil Belajar Siswa SMAN 2 Malang. Jurnal Sains. 1-10.

Mulyasa, E. 2005. Menjadi Guru Profesional Menciptakan Pembelajaran Kreatif dan Menyenangkan. Bandung: Remaja Rosdakarya.

Munandar, U. 1982. Kreativitas dan Keberbakatan. Jakarta: Gramedia Pustaka Utama

Munandar, U. 1999. Mengembangkan Bakat dan Kreativitas Anak Sekolah. Petunjuk bagi Para Guru dan Orang Tua. Jakarta: Gramedia Widyasara Indonesia 
Munandar, U. 2009. Pengembangan Kreativitas Anak Berbakat. Jakarta: Rineka Cipta.

Nur, M. \& Wikandari, P. R. 2000. Pengajaran Berpusat Kepada Peserta didik Dan Pendekatan Konstruktivis Dalam Pengajaran. Surabaya: Universitas Negeri Surabaya University Press.

Retno, P. 2010, Pengaruh Model Pembelajara Inkuiri Terbimbing (Guide Inquiry) untuk Meningkatkan Hasil Belajar dan Kemampuan Berfikir Tingkat Tinggi (High Order Thinking Skill) Siswa Kelas X SMA Negeri 1 Malang Pada Pokok Bahasan Hidrokarbon. Skrips. Malang: Universitas Negeri Malang.

Rustaman, N. 2005. Strategi Belajar Mengajar Biologi. Malang: UM Press

Sandra, E., Cain \& Jack, M. E. 1990. Sciencing: An Involvement Approach to Elementary Science Methods. Third Edition. Toronto: Merill Publishing Company.

Sanjaya, W. 2005. Pembelajaran dalam Implementasi Kurikulum Berbasis Kompetensi. Jakarta: Kencana.

Semiawan, C. 1992. Pendekatan Keterampilan Proses: Bagaimana Mengaktifkan Siswa dalam Belajar. Jakarta: Gramedia Widiasarana Indonesia.

Semiawan, C.. 2002. Dimensi Kreatif Dalam Filsafat Ilmu. Bandung. Remaja Rosada Karya.

Soeparwoto. 2004. Evaluasi Layanan Bimbingan Konseling. Semarang. Unnes.

Sudjana, N. 2009. Penilaian Hasil Belajar Mengajar. Bandung: Remaja Rosadakarya.

Sugiyono. 2011. Metode Penelitian Pendidikan. Bandung. Alfabeta

Suryabrata, B. 1991. Proses Belajar Mengajar di Sekolah. Jakarta: Rineka Cipta.

Tajalli, F, B,. Zandi, Z. 2010. Creativity comparison between students who studied life skills courses and those who didn't. Procedia Social and Behavioral Sciences 5 (2010) 13901395

Torrance, E. P. 1974. Future Careers for Creativity Student. Gilfred Child: Quarterly.

Trianto. 2010. Mendesain Model Pembelajaran Inovatif-Progresif. Jakarta: Kencana.

Widyaningsih, S, Y,. Haryono. Saputro, S,. 2012. Model MFI dan POGIL ditinjau dari Aktivitas belajar dan Kreativitas Siswa terhadap hasil Belajar. Jurnal Inkuiri 1 (3) 266275. 